Linda Kusumastuti Wardana

Program Vokasi, Program Studi D 3

A kuntansi U M Y

Jalan Brawijaya Tamantirto, K asihan,

Bantul, DI. Yogyakarta 55183

Email: lindawardana@umy.ac.id

\section{Pengolahan Air Mineral dalam Kemasan Rendah Kontaminasi}

https:/ / doi.org/ 10.18196/ bdr.6243

\begin{abstract}
ABSTRAK
Tirta Polengan merupakan merupakan produk olahan dari sumber air murni kaki Gunung Merapi di Dusun Lembar, Desa Polengan, Kecamatan Srumbung, Kabupaten Magelang, Jawa Tengah menjadi air minum dalam kemasan rendah kontaminasi. Teknologi yang digunakan untuk mengolah sumber air tersebut menjadi air minum adalah Reverse Osmosis (RO). Pelaksanaan program dibagi menjadi tiga tahapan, pertama adalah pra program, tahap pelaksanaan program, dan keberlanjutan program. Tahap pra program dirinci menjadi 4 kegiatan yaitu dimulai dengan observasi, menyiapkan alat dan bahan, membentuk kelompok usaha, dan merancang desain label serta kemasan. Tahap pelaksanaan program dirinci menjadi 7 kegiatan yaitu meliputi sosialisasi program kepada masyarakat setempat, perbaikan dan penambahan cabang saluran air, pemasangan penampungan air, pemasangan alat Reverse Osmosis (RO), uji coba produk, pelatihan produksi dan pengemasan, dan pendampingan produksi serta pengemasan. Hasil dari program ini adalah adannya pandangan baru masyarakat setempat bahwa sumber air yang selama ini tidak bernilai ekonomis dapat dimanfaatkan dan diolah menjadi produk yang bernilai jual. Selain itu, timbul motivasi masyarakat setempat untuk menjalankan unit usaha bersama dalam bidang pengolahan air minum dalam kemasan rendah kontaminasi yang diharapkan dapat meningkatkan perekonomian masyarakat dalam jangka panjang. Program ini tidak hanya bermuara pada terciptanya produk, rencana lanjutan program ini adalah dengan melakukan pendampingan pemasaran produk baik secara online maupun offline dan diversifikasi produk Tirta Polengan.
\end{abstract}

Kata kunci: Tirta Polengan, Reverse Osmosis, mata air pegunungan, air minum rendah kontaminasi

\title{
PENDAHULUAN
}

D esa Polengan merupakan salah satu desa di Kecamatan Srumbung M agelang Jawa Tengah dengan luas $4 \mathrm{Km}^{2}$ dengan $60 \%$ merupakan lahan pertanian. D esa ini terletak di sebelah barat kaki G unung M erapi yang mempunyai radius kurang lebih $11 \mathrm{Km}$ dari puncak gunung dan terdiri dari 4 dusun yaitu: Polengan, Kronggahan, Gejayan, Babadan, Larangan, Lembar, dan Gowok. Jumlah penduduk D esa Polengan adalah 2.156 jiwa dengan mayoritas mempunyai mata pencaharian menanam sawi, kacang panjang, pepaya, 


\section{3}

serta budidaya salak pondoh. Selain mempunyai produk unggulan sayur dan buah, hampir di setiap dusun yang berada di D esa Polengan mempunyai sumber mata air pegunungan murni. Tidak terkecuali di Dusun Lembar. M ata air tersebut ditampung dalam sebuah bak besar di kaki Gunung M erapi, kemudian dialirkan menggunakan pipake pemukiman warga. Warga setempat memanfaatkan mata air tersebut untuk kebutuhan sehari-hari dan menyiram tanaman pertanian, belum ada yang memanfaatkan secara ekonomis. Keunggulan sumber mata air di D usun lembar adalah debit airnya stabil sepanjang tahun, nahkan ketika musim kemarau.
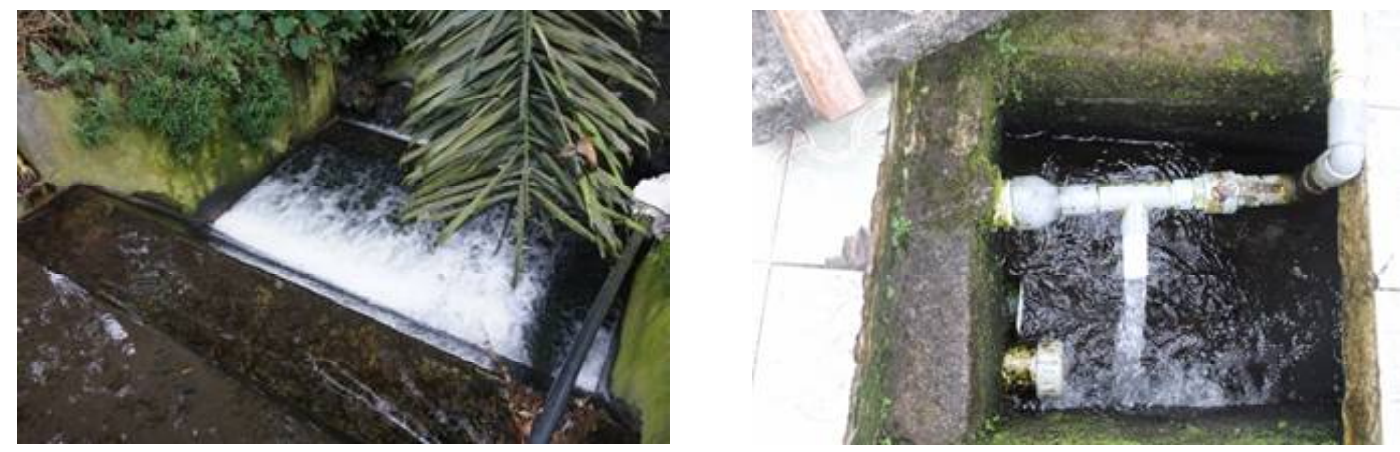

Gambar 1.Sumber Mata Air Dusun Lembar
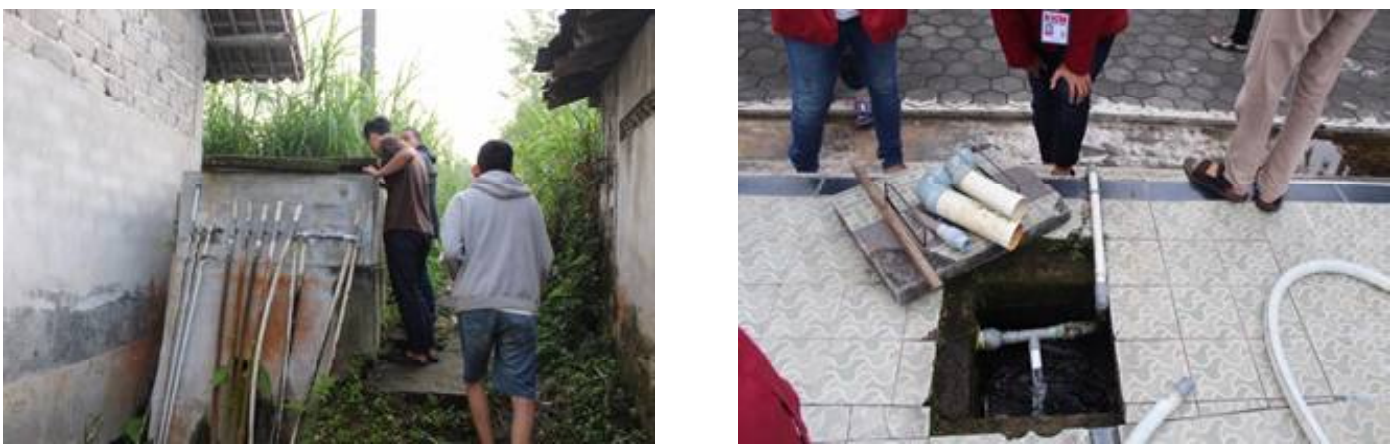

Gambar 2.Aliran Pipa dari Penampungan Air ke Rumah Warga

Perekonomian masyarakat D usun Lembar tergolong bukan merupakan ekonomi yang berkecukupan. Berdasarkan uraian di atas, penulis bermaksud untuk memanfaatkan potensi sumber mata air Gunung M erapi tersebut menjadi air minum dalam kemasan rendah kontaminasi guna untuk meningkatkan penghasilan masyarakat setempat. Adapun jen is air minum menurut Pasal 2 Kepmen Kesehatan RI Nomor 907/ M enkes/ SK / VII/ 2001 seperti air yang didistribusikan melalui pipa untuk keperluan rumah tangga; air yang didistribusikan melalui tangki air; air kemasan; dan air yang digunakan untuk produksi bahan makanan dan minuman yang disajikan kepada masyarakat harus 
memenuhi syarat kesehatan air minum. Persyaratan kesehatan air minum tersebut sebagaimana dimaksud pada Pasal 2 Ayat 1 Kepmen Kesehatan RI N omor 907/ M enkes/ SK/ VII/ 2001 adalah air yang bebas dari bakteriologis, kimiawi, radioaktif, dan fisik. Sumber mata air Dusun Lembar sudah diujicobakan di Laboratorium Kesehatan M asyarakat Dinas Kesehatan Pemerintah Kabupaten M agelang. H asil uji laboratorium tersebut menunjukkan bahwa terdapat kandungan bakteri E scherichia C oli cukup rendah yaitu sebesar 4,0. $\mathrm{H}$ asil tersebut di bawah nilai ambang batas maksimum yaitu 10 . Selain itu, hasil uji laboratorium tersebut juga menunjukkan bahwa sumber air D usun Lembar men gandung besi yang sangat kecil yaitu sebesar $0,028 \mathrm{mg} / \mathrm{L}$ dengan toleransi kandungan besi dalam air minum adalah sebesar $1 \mathrm{mg} / \mathrm{L}$. Berdasarkan hasil uji laboratorium tersebut dapat disimpulkan sumber air Dusun Lembar layak untuk dikonsumsi dan rendah kontaminasi.

M enurut Said Sutomo (2008) air merupakan salah satu kebutuhan yang sangat vital bagi manusia. Tidak semua air layak untuk dikonsumsi. Jika manusia mengkonsumsi air yang kurang baik kualitasnya, maka dapat menyebabkan berbagai penyakit (Sidharta, 2007). H anya air tanah dari sumber mata air pegunungan yang dapat diolah menjadi air minum. Ada beberapa metode untuk mengolah dan pemurnian air menjadi air layak minum menurut Amrih (2007) yaitu; pertama, melalui proses pengendapan. Air yang diproses diendapkan dalam beberapa waktu, kemudian diambil beberapa centimeter dari permukaan. K edua, penyaringan multimedia, yaitu dengan cara menyaring air dengan menggunakan berbagai media seperti batu, pasir, sabut kelapa dan kerikil. K etiga, softener, proses ini dengan cara menggunakan pelunak seperti A nion Exchange dalam mengolah air. Tujuannya adalah mengurangi kadar ion mineral bebas dalam air. K eempat, penyaringan mikro, yaitu dengan menggunakan saringan yang seperseribu lebih kecil dari penyaringan multimedia. K elima, penyaringan ultra, yaitu dengan menggunakan saringan seperseratur lebih kecil dari penyaringan mikro. K eenam, teknologi Reverse $0 \mathrm{~s}$ mosis (RO), yaitu penyaringan dengan menggunakan membaran semi permeable dan banyak digunakan di depot-depot air minum. Keunggulan teknologi ini adalah dapat mengolah air menjadi air layak minum rendah kontaminan. O leh karena itu, proses produksi Tirta Polengan menggunakan teknologi RO .

Kelompok pengolahan air minum murni dalam kemasaan akan dipusatkan dalam sebuah kelompok kecil beranggotakan masyarakat setempat 1-5 orang. BU M DES D esa Polengan bersedia menjadi mitra dari segi pendanaan untuk modal kerja kepada kelompok usaha Tirta Polengan tersebut dan nantinya melakukan sistem pembagian keuntungan 
sesuai dengan kontrak. Kemudian, tim pengusul melaksanakan kegiatan pendampingan pengolahan air minum murni kepada kelompok tersebut. Kegiatan pendampingan yang dilakukan meliputi cara mengoperasikan mesin pengolah air menjadi air minum murni, proses pengemasan, proses uji laboratorium, prosespen gajuan IRT, dan pemasaran dengan mendatangkan narasumber dari U MY Tirta untuk memotivasi masyarakat. Kegiatan pendampingan kepada masyarakat bertujuan agar masyarakat dapat man diri menjalankan unit usaha tersebut ketika tim pen gusul tidak dapat mendampingi secara langsung.

Proses pendampingan pada periode ini mempunyai target capaian terealisasinya produk air minum murni dalam bentuk gelas dan botol dan mampu memasarkan secara sederhana produk tersebut sebagai alternatif air minum terutama untuk acara desa. Pendampingan selanjutnya adalah pendampingan diversifikasi produk dan pendampingan pemasaran untuk memperluas pangsa pasar.

\section{METODE PELAKSANAAN}

Penulis membagi metode pelaksanaan kegiatan menjadi 3 tahapan. Ketiga tahapan tersebut terangkum pada Gambar 1. di bawah ini.

\section{Pra Program}

Tahap persiapan program ini dirinci menjadi 3 kegiatan sebagai berikut:

\section{a. Observasi}

Penulis melakukan observasi sebelum pelaksanaan kegiatan dengan tujuan mengidentifikasi masalah yang ada di Dusun Lembar, khususnya yang berhubungan dengan program pengolahan air minum dalam kemasan. Secara rinci, hasil observasi dan tindak lanjut masalah disajikan pada Tabel 1.

Tabel 1. Hasil Observasi dan Tindak Lanjut Masalah

\begin{tabular}{cll}
\hline NO. & \multicolumn{1}{c}{ HASIL OBSERVASI } & \multicolumn{1}{c}{ TINDAK LANJUT } \\
\hline 1. & $\begin{array}{l}\text { Pipa saluran sumber air diameternya terlalu } \\
\text { kecil sehingga debit air yang mengalir ke } \\
\text { area rumah warga kecil }\end{array}$ & M engganti pipa yang berdiameter lebih besar \\
2. & $\begin{array}{l}\text { Rumah warga untuk tempat produksi } \\
\text { memiliki pipa dari sumber air yang terbatas, } \\
\text { hanya cukup untuk keperluan pribadi } \\
\text { sehari-hari. }\end{array}$ & M enambah saluran pipa (kran) khusus untuk \\
Belum ada penampungan air di rumah & Pemasangan penampungan air untuk \\
warga yang ditunjuk & mengantisipasi debit air alirannya tidak lancar \\
\hline
\end{tabular}




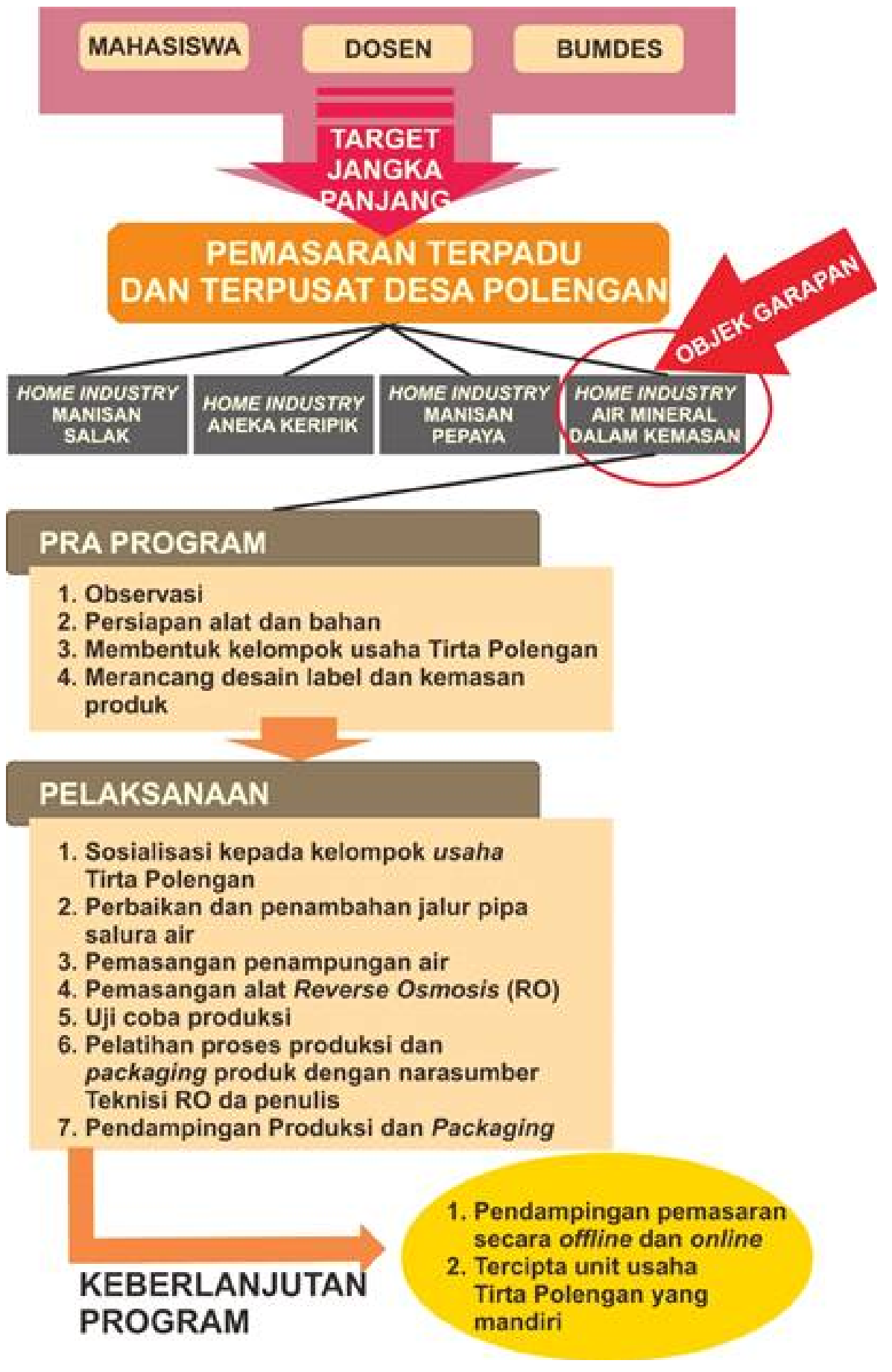

Gambar 3. Tahapan Pelaksanaan Program

\section{b. Menyiapkan Alat dan Bahan}

Setelah melakukan observasi dan menemukan masalah terkait pelaksanaan program, penulis menyusun daftar barang yang diperlukan untuk tindak lanjut masalah dan pelaksanaan program. Beberapa persiapan yang dilakukan adalah sebagai berikut: 1) membeli alat Reverse 0 smosis (RO ) untuk pemurnian sumber air dan filtrasi 


\section{7}

2) membeli cup sealer untuk mengemas AM DK dalam kemasan berbentuk gelas

3) membeli pipa air, kran air, dan peralatan pelengkap lainnya

\section{c. Membentuk Kelompok Tirta Polengan}

Penulis membentuk kelompok kecil dari anggota masyarakat D usun Lembar sebagai penanggung jawab program Tirta Polengan. Kelompok berisi 5-10 orang anggota masyarakat dengan nama kelompok usaha Tirta Polengan. $\mathrm{Hal}$ ini bertujuan untuk pemberdayaan dan kaderisasi kepada masyarakat dengan harapan bahwa program Tirta Polengan tetap berjalan ketika penulis tidak dapat ikut andil secara langsung.

\section{d. Merancang Desain Label dan Kemasan Produk}

Sebelum terjun secaralangsung ke lapangan, penulismempersiapkan kemasan produk AM DK dan desain label. D esain dirancang sesuai dengan produk yang akan ditawarkan dan dapat mewakili keunggulan produk. Label produk dalam kemasan Tirta Polengan disajikan pada Gambar 4.

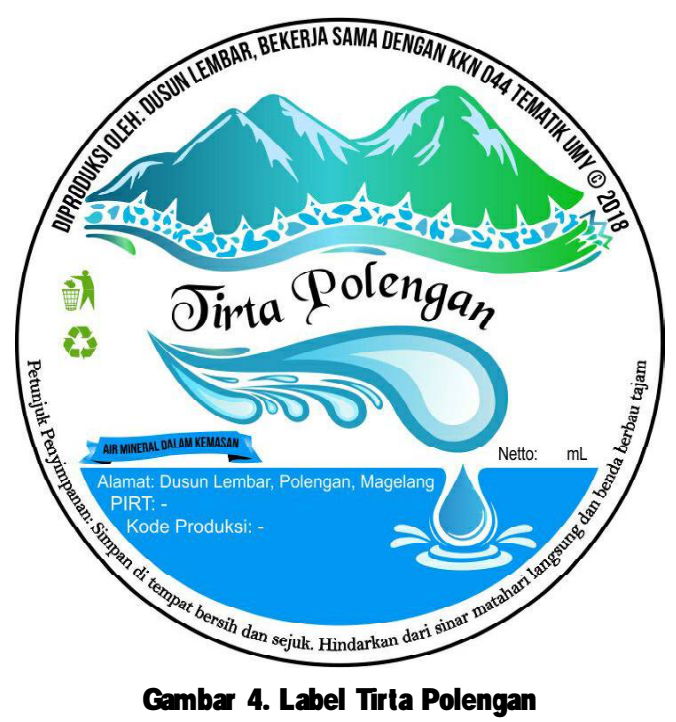

2. Tahap Pelaksanaan

\section{a. Sosialisasi kepada M asyarakat tentang Prospek Tirta Polengan}

Sosialiasi prospek Tirta Polengan dilakukan dengan mendatangkan narasumber dari U MY Tirta. Tujuannya adalah agar warga setempat termotivasi untuk menjalankan usaha AM DK Tirta Polengan dengan cara memaparkan prospek ke depan tentang usaha ini.

\section{b. Perbaikan dan Penambahan Cabang Pipa Saluran Air}

Sebelum proses produksi dilaksanakan, penulis memastikan peralatan penunjang 
sudah tersedia dengan baik. Penulis dan tim bersama warga bergotong royong memperbaiki pipa saluran air dengan cara mengganti pipa dengan diameter yang lebih besar dan menambah jalur saluran pipa air khusus untuk produksi Tirta Polengan. Kegiatan perbaikan dan penambahan cabang pipa saluran air dapat dilihat pada G ambar 5.
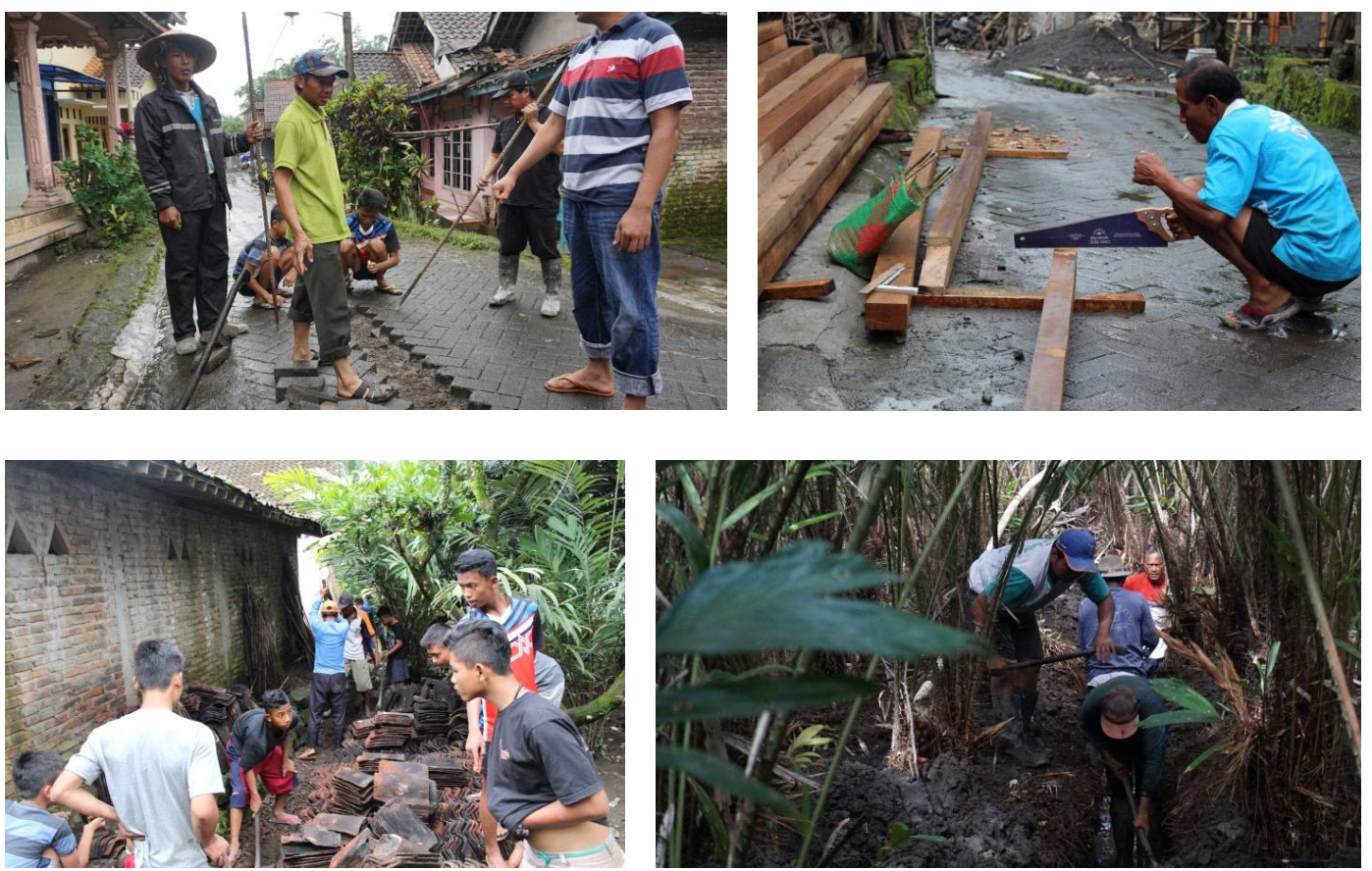

Gambar 5. Proses Perbaikan dan Pemasangan Saluran Pipa Air

\section{c. Pemasangan Penampungan Air}

Sumber air dari kaki G unung M erapi nantinya akan dialirkan ke rumah warga yang ditunjuk kemudian ditampung dalam penampungan air. $\mathrm{H}$ al tersebut dilakukan untuk men gantisi pasi ketika debit air dari hulu kuantitasnya berkurang, sedangkan produksi harustetap berjalan. O leh karena itu penulis dan warga setempat bersama-sama melakukan pemasangan penampungan air di kediaman Bapak Budi.

\section{d. Pemasangan Alat Reverse Osmosis (RO)}

Alat Reverse 0 smosis (RO) dipasang di salah satu rumah warga yang akan menjadi tempat produksi Tirta Polengan yaitu kediaman Bapak Budi. Alat digunakan sebagai alat pemurni sumber air rendah dengan kontaminasi. 


\section{9}

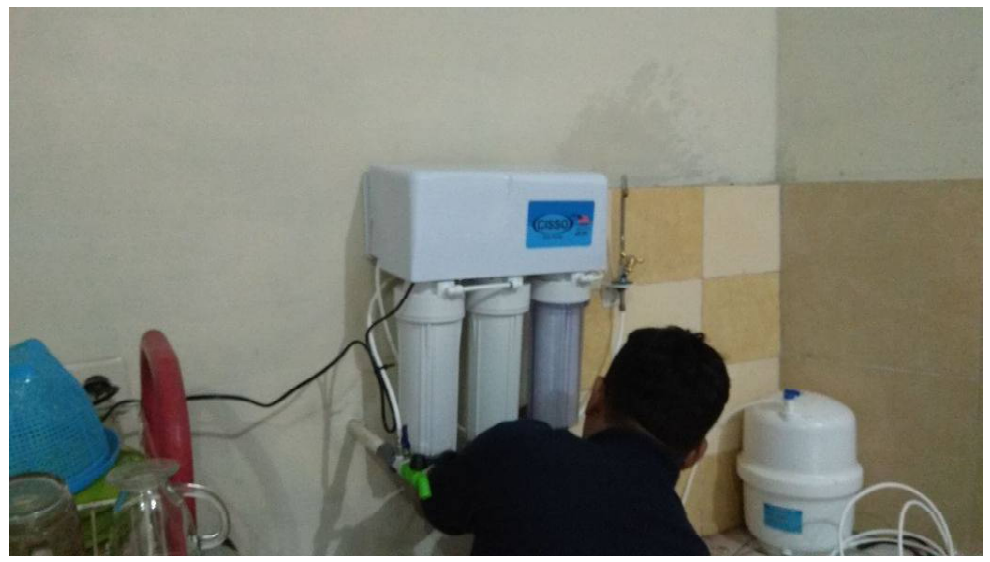

Gambar 6. Proses Pemasangan Alat Reverse Osmosis (R0)

\section{e. U ji Coba Produksi Tirta Polengan}

Penulis melakukan uji coba produk terlebih dahulu sebelum melakukan sosialisasi kepada masyarakat. $\mathrm{H}$ al itu bertujuan untuk memastikan hasil pengolahan sumber air D usun Lembar benar-benar layak konsumsi.

\section{f. Pelatihan Pengolahan Tirta Polengan}

Pelatihan pengolahan Tirta Polengan dilakukan dengan mendatangkan narasumber dari teknisi Reverse 0 smosis (RO). Narasumber memperagakan cara penggunaan alat. Kemudian, penulis dan tim memperagakan proses pengemasan produk menggunakan sealer cup ke dalam gelas dan botol. Pelatihan ini dilaksanakan sebanyak 2 kali.
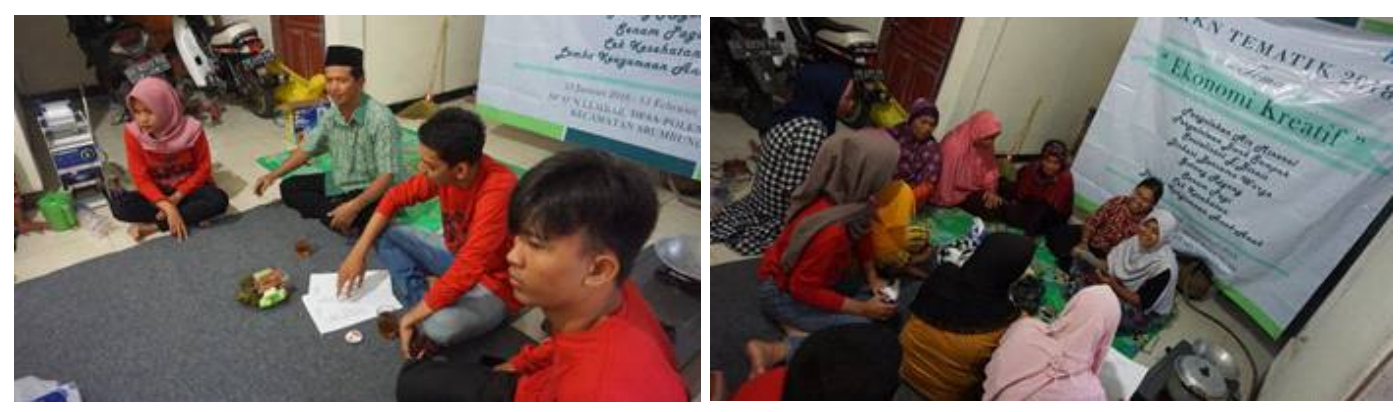

Gambar 7. Pelatihan Pengolahan Tirta Polengan

\section{g. Pendampingan Produks dan PengemasanTirta Polengan}

Pada tahap ini, anggota kelompok usaha Tirta Polengan dilatih untuk melakukan produksi secara mandiri sampai dengan pengemasan. Penulis dan tim bertindak sebagai fasilitator dan men gawasi proses produksi. 


\section{Keberlanjutan Program}

Program pengolahan Tirta Polengan tidak selesai hanya pada tahap produk sudah dapat diproduksi. Pada program selanjutnya, pen ulis dan tim akan melaksanakan beberapa program lanjutan seperti, pengajuan IRT atau izin produk, pengajuan izin usaha, dan pelatihan pemasaran produk secara offline dan online.

\section{HASIL DAN PEMBAHASAN}

\section{Pra Program}

Pelaksananaan pra program di lapangan dilakukan dalam rentang waktu 1 bulan. Pelaksanaan pra program diawali dengan obervasi; menyiapkan alat dan bahan; membentuk kelompok usaha yang khusus bertanggung jawab dalam produksi dan pengemasan Tirta Polengan; dan terakhir adalah merancang desain label dan kemasan. $\mathrm{H}$ asil dan capaian kegiatan pra program tersaji pada Tabel 2. di bawah ini:

Tabel 2. Hasil dan Capaian Pelaksanaan Pra Program

\begin{tabular}{|c|c|c|}
\hline NO. & TAHAPAN KEGIATAN & HASIL DAN CAPAIAN \\
\hline 1. & Observasi & $\begin{array}{l}\text { Mengetahui permasalahan dan hal-hal atau } \\
\text { rancangan program yang harus dipersiapkan } \\
\text { sebelum pelaksanaan program }\end{array}$ \\
\hline 2. & Menyiapkan Alat dan Bahan & $\begin{array}{l}\text { Pengadaan peralatan penunjang seperti pipa } \\
\text { dan kran air, serta alat Reverse Osmosis (RO) }\end{array}$ \\
\hline 3. & M embentuk Kelompok Tirta Polengan & $\begin{array}{l}\text { Kelompok usaha Tirta Polengan berhasil } \\
\text { dibentuk dengan beranggotakan } 7 \text { orang } \\
\text { dengan ketua Bapak Budi. }\end{array}$ \\
\hline 4. & $\begin{array}{l}\text { Merancang Desain Label dan Kemasan } \\
\text { Produk }\end{array}$ & $\begin{array}{l}\text { Ada } 2 \text { jenis kemasan Tirta Polengan yaitu } \\
\text { kemasan gelas dan kemasan botol } 330 \mathrm{ml} \\
\text { dengan label seperti pada Gambar } 4 \text {. di atas. }\end{array}$ \\
\hline
\end{tabular}

\section{Pelaksanaan Program}

Pelaksanaan program pengolahan Tirta Polengan dilakukan dalam 7 tahap. Tahap pelaksanaan diawali dengan sosialisasi kepada kelompok masyarakat tentang prospek Tirta Polengan; perbaikan dan penambahan cabang pipa saluran air; pemasangan penampungan air; pemasangan alat Reverse 0 smosis (RO); uji coba produk; pelatihan produksi Tirta Polengan; dan pendampingan produksi dan pengemasan Tirta Polengan. H asil dan capaian tahap pelaksaaan tersaji pada Tabel 3.

\section{Dampak Implementasi Program}

Efek dari pelaksanaan seluruh rangkaian program dapat terlihat dari beberapa indikator 
keberhasilan. Pertama, masyarakat D usun Lembar, D esa Polengan, Kecamatan Srumbung, $M$ agelang mempunyai pandangan baru bahwa sumber air yang selama ini hanya dimanfaatkan untuk kebutuhaan sehari-hari dan menyiram tanaman mempunyai nilai ekonomis den gan cara men golah menjadi air minum dal am kemasan rendah kontaminasi Tirta Polengan. Selain itu, masyarakat mempunyai motivasi untuk melakukan usaha sebagai alternatif meningkatkan perekonomian rumah tangga. Kedua, terciptanya kelompok usaha yang bergerak dalam bidang pen golahan sumber air asli D usun Lembar menjadi Tirta Polengan air minum dalam kemasan rendah kontaminasi. Dengan pendampingan yang intensif ke depannya, diharapkan usaha ini mampu meningkatkan perekonomian warga setempat.

Tabel 3. Hasil dan Capaian Pelaksanaan Program

\begin{tabular}{|c|c|c|}
\hline NO. & TAHAPAN KEGIATAN & HASIL DAN CAPAIAN \\
\hline 1. & $\begin{array}{l}\text { Sosialisasi kepada kelompok } \\
\text { masyarakat tentang prospek Tirta } \\
\text { Polengan }\end{array}$ & $\begin{array}{l}\text { Masyarakat menyambut baik Tirta Polengan dan } \\
\text { mempunyai pandangan baru bahwa Tirta Polengan } \\
\text { mempunyai prospek yang baik dalam jangka } \\
\text { panjang dapat meningkatkan perekonomian }\end{array}$ \\
\hline 2. & Perbaikan dan Penambahan Cabang & $\begin{array}{l}\text { Debit air semakin deras dan lancar, serta saluran air } \\
\text { khusus untuk Tirta Polengan sudah terpasang }\end{array}$ \\
\hline 3. & $\begin{array}{l}\text { Pipa Saluran Air } \\
\text { Pemasangan Penampungan Air }\end{array}$ & $\begin{array}{l}\text { Penampungan sumber air untuk produksi Tirta } \\
\text { Polengan Sudah terpasang }\end{array}$ \\
\hline 4. & Pemasangan Alat Reverse Osmosis & $\begin{array}{l}\text { Alat Reverse Osmosis (RO) berhasil dipasang di } \\
\text { kediaman Bapak Budi }\end{array}$ \\
\hline 5. & $\begin{array}{l}\text { (RO) } \\
\text { Uji Coba Produksi Tirta Polengan }\end{array}$ & $\begin{array}{l}\text { Hasil uji coba menunjukkan bahwa produk Tirta } \\
\text { Polengan aman untuk dikonsumsi dan siap } \\
\text { diproduksi serta dipasarkan }\end{array}$ \\
\hline 6. & Pelatihan Produksi Tirta Polengan & $\begin{array}{l}\text { Kelompok usaha mengetahui teknik pengolahan } \\
\text { Tirta Polengan dan pengemasannya sehingga } \\
\text { tercipta produk air dalam kemasan dengan merk } \\
\text { dagang Tirta Polengan }\end{array}$ \\
\hline 7. & $\begin{array}{l}\text { Pendampingan Produksi dan } \\
\text { PengemasanTirta Polengan }\end{array}$ & $\begin{array}{l}\text { Kelompok usaha Tirta Polengan mampu } \\
\text { memproduksi dan mengemas produk secara } \\
\text { mandiri }\end{array}$ \\
\hline
\end{tabular}

\section{SIM PULAN}

Program pemberdayaan masyarakat melalui pendampingan pengolahan sumber air D usun Lembar, D esa Polengan, Kecamatan Srumbung, M agelang dapat memberikan alternatif pemecahan masalah yang terjadi di masyarakat antara lain adalah sebagai berikut: 1. M asyarakat setempat mempunyai pandangan baru bahwa sumber air yang selama ini tidak bernilai ekonomis dapat menjadi produk yang bernilai jual

2. Masyarakat setempat mempunyai motivasi untuk melakukan usaha khususnya di 
bidang pengolahan air minum dalam kemasan dengan memanfaatkan potensi setempat

3. M asyarakat setempat mempunyai usaha bersama Tirta Polengan yang diharapkan dalam jangka panjang dapat menjadi usaha mandiri yang dapat meningkatkan perekonomian daerah setempat.

Ketercapai an program ini adalah terwujudnya produk air minum dalam kemasan Tirta Polengan di D usun Lembar D esa polengan Kecamatan Srumbung, Kabupaten M agelang dan tercipta kelompok usaha Tirta Polengan. Rencana keberlanjutan program adalah dengan mengadakan pendampingan pemasaran onlinedan offlinedan diversifikasi produk aar tercipta kelompok usaha yang mandiri.

\section{UCAPAN TERIMA KASIH}

1. LP3M U niversitas Muhammadiyah Yogyakarta, atas Program Hibah Pengabdian kepada M asyarakat dengan skema KKN Pemberdayaan pendanaan tahun 2018

2. Pemerintah D esa Polengan Kecamatan Srumbung M agelang melalui BU M DES atas kerja sama dalam mewujudkan produk Tirta Polengan

3. Perangkat dusun dan masyaarakat D usun lembar atas sambutan baik, kerja sama dan, partisipasi mulai dari persiapan sampai dengan pelaksanaan program.

\section{DAFTAR PUSTAKA}

Keputusan Menteri Kesehatan Republik Indonesia Nomor 907/Menkes/SK/VII/2002 Tentang SyaratSyarat dan Pengawasan Kualitas Air Minum Menteri Kesehatan Republik Indonesia. Peraturan Menteri Kesehatan RI Nomor 416/ MENKES/Per/IX/1990 tentang air yang digunakan untuk keperluan sehari-hari yang kualitasnya memenuhi syarat kesehatan dan dapat diminum.
Pitoyo Amrih. 2007. Dua Jam Anda Tahu Cara Memastikan Air yang Anda Minum Bukan Sumber Penyakit. Nomor seri e-buku 0500001 - 100 - 0220. Distribusi Terbuka, Solo.

Said Sutomo. 2008. Masyarakat J atim Harus Waspada Mengkonsumsi Air Minum. www.seputarair.wordpress.com., diakses tanggal 11 April 2018. 